Australian Journal of Political Science, Vol. 34, No. 3, pp. 363-377

\title{
The Impact of Proportional Representation on Turnout: Evidence from New Zealand
}

\author{
JEFFREY A. KARP AND SUSAN A. BANDUCCI* \\ University of Waikato
}

\begin{abstract}
Theories of voter turnout assume that institutional arrangements can alter incentives for participation. Countries with proportional representation (PR) are assumed to increase the incentives to participate because they reduce the proportion of votes that are wasted, giving voters a stronger incentive to participate and parties a stronger incentive to mobilise voters. This paper departs from previous cross-national studies by employing individual-level data during a transition between electoral systems in one country. We used survey data collected before and after electoral reform in New Zealand to examine patterns of participation among political minorities. As a direct test of individual change, the analysis was supplemented with survey data from the last election held under first past the post (FPP) merged with validated participation data from the following election held under PR. We found that the adoption of PR in New Zealand has succeeded initially in fostering more positive attitudes about the efficacy of voting. In New Zealand's first election held under PR, voters who were on the extreme left were significantly more likely to participate than previously, leading to an overall increase in turnout.
\end{abstract}

Faith in the assumption that institutional rules affect political behaviour often motivates advocates of political reform. Advocates of proportional representation (PR) often cite its potential for increasing citizen involvement in politics as one of the fundamental benefits over plurality or first past the post (FPP) systems. Systems that distort the translation of votes into seats may alienate and discourage minor party supporters. This alienation may result in a diminished sense of efficacy and depress turnout (Powell 1980, 1986; Jackman 1987; Jackman and Miller 1995; Blais and Carty 1990; Franklin 1996). PR rules can be seen as more 'fair' when compared with FPP systems because they reduce the proportion of voters who cast 'wasted' votes. By increasing the effective impact of individual votes, PR rules might be expected to increase attachment to and trust in a political system

\footnotetext{
* This is a revised version of a paper presented at the 1998 Annual Meeting of the Australasian Political Studies Association, 28-30 September, Christchurch, New Zealand. Funding for this research was provided by the New Zealand Foundation for Research, Science and Technology. The data used in this analysis are archived at the Social Science Data Archives (SSDA), located in the Research School of Social Sciences at the Australian National University, Canberra, Australia. More information about the data and the New Zealand Election Study (NZES) can be found at www.nzes.org. Voter validation data are available upon request. We would like to thank the New Zealand Election Study and Jack Vowles for research support. The authors can be contacted at karp@nzes.org and banducci@nzes.org.
} 
(Amy 1993). Consequently, an electoral system that ensures that the fewest votes are wasted will presumably motivate more people to vote.

Also, PR is likely to increase the number of parties and the likelihood that parties will strive to distinguish themselves. When parties fail to offer a clear choice to voters, voters will abstain (Downs 1957). The increase in parties and a tendency for them not to converge to the ideological centre should increase the options from which voters can choose resulting in fewer abstentions. Moreover, voters are likely to have stronger attachments to parties that cater more specifically to their needs as compared with catch-all parties that appeal to the median voter. Past research has shown that voters with strong party attachments are more likely to be interested in politics and more likely to vote (Campbell et al 1960; Verba, Nie and Kim 1978).

In addition to increasing political efficacy, voters are more likely to be mobilised in PR systems. Because every vote counts in PR, parties have an incentive to mobilise everywhere, resulting in competitive elections (Gosnell 1930; Tingsten 1937). In contrast, plurality systems typically favour a two party system where parties are separated by small margins in a relatively small number of seats (Downs 1957). In single member district (SMD) systems, parties have an incentive to concentrate their resources on marginal or competitive races and neglect those where the outcome is more certain. In those districts that are non-competitive, voters have less of an incentive to vote and parties have less of an incentive to mobilise (Powell 1980, 12).

Recent reform proposals in New Zealand and the UK are based on many of these expectations. After considering alternative electoral systems, in 1986, a royal commission in New Zealand concluded from its inquiry that PR would produce results that are more fair, make voting more effective and satisfying, and enhance the representation of women and Maori, who are the primary ethnic minority in New Zealand. Relying on both theory and empirical evidence, the commission argued that under PR, voters in safe constituency seats would have more of an incentive to participate because the choice of government would be determined by the nation-wide party vote, not by a relatively small number of voters in marginal electorates. 'We consider that the greater effectiveness of votes [under PR] would be likely to result in a turn-out higher than under plurality' (Royal Commission 1986, 55). These recommendations served as the basis for the adoption of PR in New Zealand in 1996. In the UK, an independent commission established by the government in 1997 to consider an alternative electoral system recommended the adoption of PR for similar reasons (Independent Commission 1998, 126).

\section{The Empirical Evidence}

While theory suggests that PR has advantages that may give some voters more of an incentive to vote, the empirical evidence is largely inconclusive. Most empirical studies that attempt to measure the impact of institutional arrangements on turnout do so by employing aggregate data across a number of countries with different electoral systems. Although both the model specification and the selection of cases vary significantly from one study to another, most find that higher turnout is associated with countries that have PR. However, it is not at all clear whether PR actually causes higher turnout nor is it clear how PR systems influence political participation. For example, while PR is associated with higher turnout, according to Powell $(1980,12)$ much of the association seems to be due to permissive 
registration laws and compulsory voting, which are frequently present in PR systems. Controlling for these factors, Lijphart found, on average, turnout in consensus democracies to be $7.5 \%$ higher than majoritarian systems and that much of this difference was due to PR rules in consensus democracies (1999, 284-5). Blais and Carty (1990) compared turnout among 20 parliamentary systems with various electoral systems from 1919 to 1985 and found that turnout was also about $7 \%$ higher in PR systems than plurality systems. However, they were unable to explain the reasons for the difference as none of their measures through which PR is assumed to affect turnout (disproportionality, number of parties, and competitiveness) were significant. Franklin $(1996,226-7)$, on the other hand, found that disproportionality has a negative influence on turnout, and he concluded that countries with PR should on average produce a $12 \%$ increase in turnout.

Although PR systems may seem to offer voters more choice, critics argue that PR may in fact offer less of a choice because the process of government formation is often left to the bargaining of political elites. As a result, voters have less direct involvement in selecting a government. Where elections are less important, citizens have less of an incentive to vote (Downs 1957). Along these lines, Jackman and Miller (1995) offer empirical evidence demonstrating that multipartyism, often associated with PR systems, depresses turnout. Yet, this finding is inconsistent with the expectation that parties increase turnout by mobilising voters as well as offering greater choice. In a more recent study which supports Jackman and Miller's conclusions, Blais and Dobrzynska (1998) found that multipartyism decreases turnout but that both proportionality and competitiveness foster higher turnout. The result, according to Blais and Dobrzynska $(1998,251)$ is that PR has both positive and negative effects, with the overall impact being a slightly positive one of $3 \%$.

In short, the findings from these studies suggest that PR should foster higher turnout but are not conclusive when it comes to explaining just how much turnout should increase under PR or, for that matter, who it is that is most likely to be influenced by institutional arrangements. For example, we would expect minor party supporters to be less likely to vote under institutional rules that do not allow minor parties to translate their support into seats. The theory that the prospect of a coalition government offers a disincentive to vote would appear to apply only to those large or 'major' parties that would otherwise govern alone under a plurality system but must share power in a coalition under a proportional system. Given the potential for minor parties to play a crucial part in forming a government, we would not expect those supporting small parties to be less likely to vote in systems that encourage the formation of coalition governments. ${ }^{1}$

Part of the difficulty in determining the relationship between electoral systems and turnout is the reliance on proxy variables and aggregate turnout to draw inferences about the interactions between institutions and individual behaviour such as voting and attitudes such as efficacy. While these cross-national studies are useful, these hypotheses can best be tested with individual-level data. Another shortcoming with cross-national studies is with the design itself. All of the aforementioned studies employed cross-sectional data. A stronger case can be made regarding the impact of institutional rules on behaviour using a quasi-experimental design in countries where institutional rules have changed. For example,

\footnotetext{
${ }^{1}$ An exception might be in the case of small parties that are so extreme that they have no reasonable chance of entering into a coalition with other parties.
} 
cross-national comparisons of countries with and without compulsory voting have found that turnout is about $10 \%$ higher in countries with mandatory voting, although other researchers (Crepaz 1990) have found that these differences go away in a multivariate analysis. The case is much stronger if one examines turnout before and after the imposition of compulsory voting, for example, in Australia in 1924. From 1901 to 1922 turnout for the House of Representatives averaged 64\%; from 1925 to 1998 turnout averaged 95\% (Australian Electoral Commission 1999). Similarly, Hirczy's (1994) analysis of changes in compulsory voting laws in Austria provides stronger evidence that mandatory voting, although difficult to enforce, increases political participation.

Although changes in electoral rules are rare, they provide an alternative method for testing these theories. The advantage of a quasi-experimental design is that many of the variables possibly affecting political participation, such as compulsory enrolment, political culture, and social cleavages are constants while our variable of interest-the electoral system-varies within the country. As discussed earlier, electoral change occurred in New Zealand when voters approved a referendum in 1993 changing the country's electoral system from FPP to PR. New Zealand adopted a mixed compensatory system similar to Germany's electoral system. Voters cast one vote for their local Member of Parliament (MP) and another for a party. Parties receiving more than $5 \%$ of the vote are represented in Parliament in proportion to their vote. Of the 120 MPs in Parliament, 65 seats are held by MPs elected in single member constituencies by FPP. The remaining 55 seats are held by MPs on party lists. While it may take years to determine its full impact, some of the effects should be more immediate. New Zealand, thus, provides a rare opportunity to examine how PR influences political participation at the individual level.

\section{Political Participation in New Zealand}

Having had both full universal male and female suffrage since 1893, New Zealand is one of the oldest modern democracies. Although not strictly enforced, citizens and residents are required by law to enrol, resulting in high enrolment numbers; approximately $92 \%$ of the eligible voting age population are enrolled to vote (Electoral Commission 1997, 127). Persons of Maori descent, who have had the option of enrolling on either the general roll or a separate roll to elect Maori representations are less likely than non-Maori to be enrolled (Vowles and Aimer 1993, 51).

Turnout among the eligible population averaged $82 \%$ in the $1980 \mathrm{~s}$ and $78 \%$ in the 1990s (under FPP) meaning New Zealand's turnout is average when compared with other Western democracies (Vowles 1994). ${ }^{2}$ Like many other countries in the OECD, turnout in New Zealand has been declining except for a brief recovery between 1975 and 1984. Vowles (1994) attributes this decline primarily to partisan dealignment and a subsequent increase in disproportional electoral outcomes. Since 1938, when turnout began to decline, proportionality has declined as minor parties received increasingly more support but failed to gain more than a handful of seats.

\footnotetext{
${ }^{2}$ Most analysts rely on the official turnout figures which are calculated on the base of enrolled electors. This leads to inflated estimates, especially when these data are compared with other countries whose base is the eligible voting population. For a more thorough discussion of this problem, see Nagel (1988).
} 
This trend in minor party support increased sharply in the late 1970s and early 1980 s when the combined support for minor parties totalled over $20 \%$. By 1993 , small parties received $30 \%$ of the vote but under FPP rules these parties failed to win more than a few seats in Parliament.

Although growing disenchantment with the political process was one of the primary factors contributing to support for electoral reform (Lamare and Vowles 1996; Banducci and Karp 1999), close to three-quarters of the New Zealand electorate continued to express a strong sense of civic duty and efficacy about voting prior to the adoption of PR in 1993. Given this, it may be unreasonable to expect substantial increases in efficacy and civic duty after a switch from FPP to PR. Nevertheless, the three indicators of efficacy (interest, vote counts and politics complicated) and the two indicators of civic duty (voting is important and citizen's duty to vote) listed in Table 1 reveal a positive change over the course of six years. These changes, however, did not occur simultaneously. Major change in the two indicators of civic duty took place between the post-election survey of 1990 and the post-election survey of 1993, just after the referendum on electoral reform, suggesting that voters may have been persuaded by the rhetoric emphasising the importance of voting in the campaign leading up to the referendum. An alternative explanation for this increase is based on the argument that devices of direct democracy instil greater civic pride and trust in government and thereby diminish apathy and alienation (Cronin 1989, 228). Thus, the opportunity to have a direct influence on policy through a referendum could have instilled greater civic confidence.

Major change in the indicators of efficacy occurred between 1993 and 1996. People were more likely to say their vote counts in elections after the implementation of PR which is consistent with the arguments made on behalf of PR. According to PR advocates, PR rules are more fair since they reduce the proportion of voters who cast 'wasted' votes. Under the previous FPP system, about a fifth of the electorate who supported minor parties that failed to translate their support into seats may have had reason to believe that their votes had been wasted. A more detailed analysis of panel data indicates that minor party supporters were more likely to change their assessment that their vote counts than major party supporters (Banducci, Donovan, and Karp 1999), supporting these hypotheses.

One of the primary concerns raised during the reform debate was that PR might cause more confusion, with the result that voters would either cast misinformed votes or abstain. Evidence from Germany indicates that a substantial number of voters continue to misunderstand the importance of the two votes (Jesse 1988). As part of the Electoral Reform Act of 1993, the Electoral Commission was formed to 'promote public awareness of electoral matters'. The commission conducted research on public understanding in 1994 and targeted those who had low levels of interest in politics and low levels of knowledge about the political system with a television campaign. Results from the commission's research indicate that the public education campaign was largely successful in increasing awareness of the primacy of the party vote and that perceived difficulties in understanding the new system did not appear to deter people from voting (Harris 1998, 19). As the data in Table 1 show, fewer people considered politics as complicated under PR than under FPP. This result is surprising when one considers that voters were confronted with a new and more complex electoral system, with two votes that translate into seats in different ways. As a consequence of reform and possibly the education 
Table 1. Change in attitudes about voting, 1990, 1993, 1996 (percentage who agree or strongly with the statement)

\begin{tabular}{lccrr}
\hline & 1990 & 1993 & 1996 & $\begin{array}{c}\text { Overall } \\
\text { change }\end{array}$ \\
\hline $\begin{array}{l}\text { Voting is important even if it makes } \\
\text { no difference to who wins }\end{array}$ & 75.6 & 81.6 & 81.4 & 5.8 \\
$\begin{array}{l}\text { It is a citizen's duty to vote } \\
\text { My vote really counts in elections }\end{array}$ & 70.5 & 82.3 & 83.9 & 13.4 \\
Very interested in politics & 76.8 & 74.7 & 85.3 & 8.5 \\
$\begin{array}{l}\text { Sometimes politics seems so } \\
\text { complicated people like me can't }\end{array}$ & 14.6 & 14.6 & 21.1 & 6.5 \\
understand what goes on & NA & 54 & 47.2 & -6.8 \\
Considered not voting & 14.2 & 11.9 & 7.6 & -6.6 \\
n & 1767 & 998 & 1520 & \\
\hline
\end{tabular}

Source: New Zealand Election Study 1990, 1993, 1996 Cross-sections

campaign, people were also more likely to be very interested in politics after the implementation of PR.

These changes in efficacy suggest that turnout should have increased both in 1993, when the referendum instilled greater confidence, and in 1996 when voters were more likely to say their vote counts. Despite the increase in civic mindedness, official voter turnout in 1993, as a percentage of the age eligible population, remained virtually unchanged at about $78 \%$. However, in 1996, turnout increased for the first time since 1984. As a percentage of the age eligible population, official turnout increased from 78 to $81 \%$. As a percentage of the enrolled electorate, official turnout increased from 85 to $88 \%$, although there was $1 \%$ fewer electors enrolled in 1996 (Electoral Commission 1997, 127). Although not large, the increase in turnout was a reversal in a downward trend and from a comparative perspective was unusual, given the fact that turnout in the 1990s was declining in most OECD countries (Wattenberg 1998). However, these aggregate figures do not tell us much about how the change in electoral systems influenced turnout. It is possible, for example, that turnout among those marginalised under FPP rules increased significantly as PR advocates expected while other voters experienced a decline, producing a net result that is not substantially different from previous elections.

Under FPP rules, we expect those who prefer minor parties to be less likely to vote than major party supporters. This follows from the expectation that voters who prefer parties that have little chance of winning will be more likely to abstain. Furthermore, under FPP, since parties are likely to tailor their platforms to the median voter, persons on the extreme right or left are likely to have less of an incentive to vote than persons in the ideological centre. We expect those residing in safe electorates to be less likely to vote than persons in marginal electorates. Under PR, political minorities should have more of an incentive to participate and

\footnotetext{
${ }^{3}$ The official voting statistics reported by the Electoral Commission in both 1993 and 1996 include disallowed votes in the numerator which increases turnout by about $2 \%$.
} 
there should be no difference in turnout between safe and marginal electorates. To examine these hypotheses, we turned to individual-level data.

\section{Individual-level Analysis}

We relied on post-election survey data from the 1990, 1993 and 1996 New Zealand Elections Studies (NZES). One of the frequently cited limitations with using survey data involves the validity of the response, particularly with regard to political participation. According to voter validation studies in the USA, between 15 and $25 \%$ of respondents are likely to report voting when they did not (Clausen 1968; Traugott and Katosh 1979). Averaging over four US elections, $88 \%$ of those interviewed appeared to be telling the truth (Anderson and Silver 1986). Among non-voters in the USA, about $27 \%$ falsely claimed to have voted compared with only $2 \%$ of voters who falsely denied having voted (Silver, Anderson, and Abramson 1986). Analysis of non-voters in Sweden and the UK indicates that over-reporting by non-voters reaches almost identical proportions, 26 and 25\%, respectively (Swaddle and Heath 1989, 539; Granberg and Holmberg 1991, 451). Given the potential for misreporting, the New Zealand Election Study embarked on its own voter validation study for the 1990, 1993, and 1996 studies. ${ }^{4}$ The results of these studies indicate that about $5 \%$ of New Zealanders misreport voting. As in the USA, Sweden, and the UK, the bulk of those misreporting are non-voters who report voting, although the proportions are somewhat lower. ${ }^{5}$ Therefore, for the analysis that follows, we used validated data which are more reliable than reported vote. We were able to obtain validated information on about $95 \%$ of the sample. The sample for the NZES was drawn from the electoral roll; therefore our analysis was confined to turnout among registered voters.

We first estimated three separate models using cross-sectional data from the 1990, 1993, and 1996 elections to test hypotheses about voter participation under FPP and PR. To examine individual change between electoral systems we used the cross-sectional data from the last election held under FPP in 1993 merged with validated participation data from the election held under PR in 1996. We were able to locate $89 \%$ of the former respondents on the 1996 general roll to determine whether they cast a vote in the 1996 election. Since we did not have to contact these respondents twice to ask them whether they participated in the following election, we avoided the problem of self-selection and testing effects that would otherwise have biased our sample.

To measure party preference, we employed a 10-point measure of each party ranging from strongly like to strongly dislike. Respondents' highest ranked party was coded as the respondents' first preference. If the preference was for either National or Labour, the respondent was identified as having a preference for a major party. Those who either refused to rank parties or ranked more than one party equally were classified in the referent category. To measure ideological classification, we used separate dummy variables to identify persons on the right,

\footnotetext{
${ }^{4}$ This involved visiting each of the 99 electorate offices following the 1993 election and each of the 65 electorates following the 1996 election to confirm whether the respondent cast a vote.

${ }^{5}$ While the percentage misreporting remained about the same across the three studies, the percentage of non-voters who overreported varied somewhat. In 1996, 23\% of non-voters claimed to have voted compared with $14.1 \%$ in 1993 and $18.1 \%$ in 1990. The percentages of voters claiming not to have voted were as follows: $2 \%(1996), 3.6 \%(1993)$ and $1 \%(1990)$.
} 
middle, and left of the ideological continuum. ${ }^{6}$ The effective referent category was non-ideologues. This was used as the reference category because it represented the largest group in the sample whereas those placing themselves on the far left and far right represented a minority of the electorate. Competitive electorates were identified as those where the plurality winner was less than $5 \%$ away from the next party. We also included a control for party identification, which involved a stronger psychological attachment to political parties than our measure of party preference. ${ }^{7}$ Because all these variables, with the exception of education and age, were dichotomous, the interpretation of the estimates was fairly straightforward.

\section{Participation Under Two Types of Electoral Systems}

Table 2 displays the results of three logistic models estimating the likelihood of voting in 1990, 1993, and 1996. Consistent with our expectations, we found that persons preferring major parties were significantly more likely to vote than those without any clear party preference in the 1990 election held under FPP. In contrast, the difference between minor party supporters and those without a preference was not significant, indicating that minor party supporters had a lower probability of voting than major party supporters. Unlike the 1990 election which may have discouraged minor party supporters from participating, the 1993 election offered voters the opportunity to vote for PR, an incentive that appealed to minor party supporters. Compared with those without a clear party preference, minor party supporters were almost four times as likely to vote. ${ }^{8}$ Major party supporters, on the other hand, were just as likely to vote as in 1990. Under PR, major parties no longer hold a distinct advantage; therefore we should not expect different participation rates for these groups. As the results indicate, the coefficients for major and minor party supporters were no longer significant, indicating that both groups had the same probability of voting as those with no clear party preference. Regardless of party preference, those who expressed a psychological attachment to a political party were consistently more likely to vote than those refusing to identify with a party.

Based on the political minorities hypothesis, we expect persons on the far ends of the ideological spectrum to be less likely to participate under FPP. However, we did not find evidence to support these hypotheses. Instead we found that persons on the far right were consistently more likely to vote than non-ideologues. Most likely this reflects satisfaction among those on the right with the existing policies of both of the major parties which had embraced a liberal agenda that took New Zealand in the space of just a few years from one of the most regulated economies in the world to one of the most deregulated. ${ }^{9}$ These policies, which were imple-

\footnotetext{
${ }^{6}$ On a seven-point scale, persons on the left and right were classified as those who placed themselves on one or two of the extreme sides of the scale.

${ }^{7}$ Relying on party identification alone as an indicator of party preference would underestim ate support for minor parties that have not been able to develop longstanding attachments. Therefore, we distinguished between partisan loyalty, as measured by identification, and party preference, as measured by thermometer ratings.

${ }^{8}$ The parameter estimate (measured in logged odds) for minor party preference was 1.34 . This positive coefficient indicates that minor party supporters were 3.8 (natural log base of $1.34\left[\mathrm{e}^{1.34}\right]$ ) times more likely to vote than the referent category, which was those without any party preference.

${ }^{9}$ Of those who were on the right in 1993 only 5\% said that the 1993-96 National government's policies had a bad effect on the country's economic situation.
} 
mented under a Labour government, alienated its supporters. The lack of a viable alternative to Labour gave those on the left little incentive to vote in the 1990 election. In 1993, however, persons placing themselves anywhere on the ideological scale were more likely to vote, with the effect being greatest for those on the left. This result is a clear reversal from 1990 and indicates that the opportunity to vote for PR attracted those primarily on the far left, who were the strongest supporters of the referendum (Lamare and Vowles 1996; Banducci and Karp 1999). The results were much the same for 1996, except the effect of being on the left was not as great as it was in 1993.

The data in Table 2 provide evidence that participation rates among Maori have continued to increase since 1990. In 1990, turnout among Maori had reached its lowest level on record with $41.5 \%$ of enrolled Maori failing to turn up at the polls (Vowles and Aimer 1993, 51). ${ }^{10}$ Low turnout among Maori may be accounted for by the fact that Maori have lower education levels, lower incomes, and are also on average younger than New Zealand Europeans. Yet even after controlling for education and age, Maori were significantly less likely to participate than nonMaori in 1990. The adoption of a party list system together with the preservation of separate Maori electorates offered Maori the ability to increase their representation, up to and perhaps beyond proportionality (Nagel 1994, 528). This gave Maori a stronger incentive to participate in the 1993 referendum, and Maori voted two to one in favour of proportional representation (Banducci and Karp 1998, 137). Turnout among Maori did increase by 4\% between 1990 and 1993, which is reflected by the smaller coefficient separating Maori from non-Maori, although the differences were still significant. In 1996, however, these differences disappeared indicating that Maori were just as likely to vote as non-Maori. These changes largely reflect an increase in aggregate turnout within the five Maori electorates which could be partly due to the increased competitiveness in the Maori electorates. ${ }^{11}$

Under FPP, turnout was suppressed somewhat in safe seats as parties put their resources into contesting the marginal electorates. Although our results show no significant differences in 1990, we did find evidence in 1993 that was consistent with the hypothesis that competitive electorates produce higher turnout. New Zealand's electoral reformers anticipated that under PR, parties would have an incentive to mobilise voters everywhere which would lead to greater participation. Under PR in 1996, we found no difference in the likelihood of voting between competitive electorates and safe electorates. ${ }^{12}$ Although this appears to indicate that

\footnotetext{
${ }^{10}$ Estimates of Maori turnout outside the Maori electorates were difficult to estimate since we had to rely on a relatively small sample of Maori who were enrolled in the general electorates. In contrast, those in the Maori electorates were oversampled in the 1996 NZES providing for a more reliable estimate. Official estimates of Maori turnout were confined to those enrolled in the Maori electorates. The low turnout in 1990 may have been due, in part, to a campaign initiated by the Maori Council of Churches to persuade Maori to sign a protest register instead of voting (Vowles and Aimer 1993; Sullivan and Vowles 1998, 173).

${ }^{11}$ Lack of competition in the Maori electorates may have depressed turnout in the past. The Maori electorates were among the safest Labour seats in the country, with Labour holding a monopoly over them from 1943 to 1993. But in 1996, Labour lost all its four seats to New Zealand First. However, it is unlikely that competition can fully explain this increase due to the fact that Maori participation has varied over the last 30 years despite Labour enjoying a virtual monopoly in these electorates.

${ }^{12} \mathrm{We}$ also analysed aggregate turnout by electorate (including the five Maori electorates) in 1996 and found no relationship between competitiveness and turnout $(\mathrm{r}=-0.03)$.
} 
Table 2. Probability of voting under first past the post (FFP) and propositional representation (PR)

\begin{tabular}{|c|c|c|c|c|c|c|}
\hline & \multicolumn{2}{|l|}{$\begin{array}{l}\text { FFP } \\
1990\end{array}$} & \multicolumn{2}{|c|}{$\begin{array}{c}\text { Referendum on PR } \\
1993\end{array}$} & \multicolumn{2}{|c|}{$\begin{array}{l}\text { PR election } \\
1996\end{array}$} \\
\hline & Coeff. & Effect & Coeff. & Effect & Coeff. & Effect \\
\hline Minor party preference & $\begin{array}{l}0.33 \\
(0.21)\end{array}$ & 1.39 & $\begin{array}{l}1.34^{* * * *} \\
(.32)\end{array}$ & 3.80 & $\begin{array}{l}.08 \\
(.27)\end{array}$ & 1.08 \\
\hline Major party preference & $\begin{array}{l}1.02 * * * \\
(.21)\end{array}$ & 2.76 & $\begin{array}{l}0.73^{* * *} \\
(0.21)\end{array}$ & 2.08 & $\begin{array}{c}0.01 \\
(0.24)\end{array}$ & 1.01 \\
\hline Partisan & $\begin{array}{l}0.40^{* *} \\
(0.16)\end{array}$ & 1.49 & $\begin{array}{l}0.47 * * \\
(0.21)\end{array}$ & 1.60 & $\begin{array}{l}0.72 * * * \\
(0.17)\end{array}$ & 2.05 \\
\hline Left & $\begin{array}{c}0.22 \\
(0.22)\end{array}$ & 1.24 & $\begin{array}{l}2.21 * * * \\
(0.61)\end{array}$ & 9.14 & $\begin{array}{l}0.71 * * \\
(0.32)\end{array}$ & 2.03 \\
\hline Middle & $\begin{array}{l}0.08 \\
(.19)\end{array}$ & 1.08 & $\begin{array}{c}0.42 * \\
(.23)\end{array}$ & 1.51 & $\begin{array}{l}0.61 * * * \\
(.23)\end{array}$ & 1.84 \\
\hline Right & $\begin{array}{l}0.62^{* *} \\
(0.25)\end{array}$ & 1.86 & $\begin{array}{l}0.65^{* *} \\
(0.32)\end{array}$ & 1.91 & $\begin{array}{l}0.50^{* *} \\
(0.23)\end{array}$ & 1.65 \\
\hline Education (5-unit scale) & $\begin{array}{l}0.18 * * * \\
(0.04)\end{array}$ & 1.19 & $\begin{array}{l}0.17 * * * \\
(0.05)\end{array}$ & 1.18 & $\begin{array}{l}0.25^{* * *} \\
(0.06)\end{array}$ & 1.28 \\
\hline Age (in years) & $\begin{array}{l}0.03 * * * \\
(0.01)\end{array}$ & 1.03 & $\begin{array}{l}0.02 * * * \\
(0.01)\end{array}$ & 1.02 & $\begin{array}{l}0.15^{* * *} \\
(0.03)\end{array}$ & 1.16 \\
\hline Non-Maori & $\begin{array}{l}1.04 * * * \\
(0.23)\end{array}$ & 2.82 & $\begin{array}{c}0.59^{*} \\
(0.32)\end{array}$ & 1.80 & $\begin{array}{c}0.41 \\
(0.25)\end{array}$ & 1.50 \\
\hline Competitive electorate & $\begin{array}{c}0.06 \\
(0.17)\end{array}$ & 1.06 & $\begin{array}{c}0.53^{*} \\
(0.27)\end{array}$ & 1.70 & $\begin{array}{c}0.06 \\
(0.25)\end{array}$ & 1.06 \\
\hline Constant & $\begin{array}{l}-1.70^{* * *} \\
(0.34)\end{array}$ & & $\begin{array}{l}-1.20^{* * * *} \\
(0.39)\end{array}$ & & $\begin{array}{c}-1.02 * * \\
(0.40)\end{array}$ & \\
\hline$-2 \log$ likelihood & 1367.11 & & 805.75 & & 1136.95 & \\
\hline Pseudo $\mathrm{R}^{2}$ & 0.16 & & 0.20 & & 0.14 & \\
\hline Cases correctly classified & $\begin{array}{r}85.11 \\
1654\end{array}$ & & 85.05 & & $\begin{array}{r}86.85 \\
1476\end{array}$ & \\
\hline
\end{tabular}

$* * * p<0.01 \quad * * p<0.05 \quad * p<0.10$

Standard errors are in parentheses.

Note: Effect is the unlogged coefficient.

parties did not neglect safe electorates by concentrating only on the marginals, we cannot be certain whether these changes in tactics contributed to greater overall mobilisation than would have been the case under FPP.

\section{Changes in Voter Turnout between FPP and PR}

The analysis discussed above suggests that although turnout in the aggregate increased only marginally, there were shifts among partisan and ideological subgroups. However, since the prior analysis relied entirely on cross-sectional data, we cannot be sure whether these differences result from individual-level change. Indeed we should not expect the same individuals who either preferred small or large parties or who placed themselves on the left or right to have the same preference three years later, particularly if these preferences are likely to be shaped, in part, by the electoral system. To examine how the change to PR affected individual-level behaviour, we relied on survey data collected in the last election held under FPP in 1993 along with participation data obtained independently from the electorate offices indicating whether the respondent voted in the 1996 election. Therefore, we were able to use preferences measured in 1993 to predict whether the 
respondent went to the polls in 1996. This design allowed us to track the same individuals across two elections, without having to interview them twice, avoiding problems of non-response and testing effects that typically characterise panel data.

The independent variables used in the individual-level change model replicate those used in Table 2 with the exception of the lagged participation variable which measured voting behaviour in 1993. As the lagged dependent variable shows, prior participation is a good predictor of future participation. Compared with those who did not vote, those who voted in 1993 were almost five times as likely to vote in 1996. In this model we were interested mainly in which groups were more likely to participate in 1996 controlling for 1993 participation. Coefficients that were positive and significant indicate when that group had a higher probability of voting in 1996.

While Table 2 shows that older respondents were more likely to vote in all elections, the size of the coefficient in 1996 indicates a stronger relationship. Table 3 shows that older voters had a significant increase in the probability of voting between 1993 and 1996. Most likely this was due to the mobilisation efforts of New Zealand First whose position on the superannuation surtax issue was appealing to older voters (Vowles et al 1998, 209-10). As for the groups expected to have increased turnout under PR, we see that persons who were on the left in 1993 were more likely to participate than previously. When one recalls from the previous analysis that these same persons were more likely to vote than any other group, the additional increase in 1996 was significant. If this increase was due to the novelty of the referendum and not a lasting change in the electoral system, we would expect a decline in turnout among this group due to 'regression towards the mean'. While not quite as strong as the effect of being on the left of the ideological spectrum, persons in the middle were also more likely to experience an increase in participation under PR. As for those supporting minor parties in 1993, we saw no further increase or decrease in their participation.

Table 4 compares the probability of voting in 1996 for non-voters and voters under FPP rules derived from the estimates in Table 3. Comparing the overall probabilities for all ideological groups in 1993, the probability of voting in 1996 among those who participated previously was high, and there was only a $10 \%$ difference in the probability of voting among non-ideologues and those on the left. Among non-voters, however, there were larger differences between the ideological groups in the probability of voting. Non-voters under FPP on the left had a much higher probability of voting than those in the middle and non-ideologues. Furthermore, the difference in the probability of voting in 1996 between non-voters and voters on the left was only $7 \%$. As was evident when considering the probabilities by age groups, the effects of being on the left were greatest for the younger group who were non-voters in 1993.

Although minor party supporters were far more likely to participate in 1993 as compared with 1990 (see Table 2), we saw no further increase (or decrease) in the likelihood of their voting under PR. These results suggest that the combination of the referendum and the implementation of PR succeeded in increasing turnout primarily among those on the left and those who supported minor parties. Because these persons only make up a modest proportion of the electorate the net effects on overall turnout were not substantial. 
Table 3. Probability of voting under proportional representation (PR) compared with first past the post (FFP)

\begin{tabular}{|c|c|c|}
\hline \multirow[b]{2}{*}{ Measures from previous election held under FPP } & \multicolumn{2}{|c|}{$\begin{array}{c}\text { Likelihood of voting under } \\
\text { PR on } 1996\end{array}$} \\
\hline & Coeff. & Effect \\
\hline Voted in 1993 & $\begin{array}{l}1.59^{* * *} \\
(0.27)\end{array}$ & 4.91 \\
\hline Minor party preference & $\begin{array}{c}0.44 \\
(0.38)\end{array}$ & 1.56 \\
\hline Major party preference & $\begin{array}{c}0.26 \\
(0.27)\end{array}$ & 1.30 \\
\hline Partisan & $\begin{array}{r}-0.06 \\
(0.25)\end{array}$ & 0.94 \\
\hline Left & $\begin{array}{c}1.85^{*} \\
(1.03)\end{array}$ & 6.36 \\
\hline Middle & $\begin{array}{r}0.52^{*} \\
(0.27)\end{array}$ & 1.69 \\
\hline Right & $\begin{array}{c}0.41 \\
(0.52)\end{array}$ & 1.50 \\
\hline Education (5-unit scale) & $\begin{array}{c}0.08 \\
(0.06)\end{array}$ & 1.08 \\
\hline Age (in years) & $\begin{array}{l}0.02^{* * *} \\
(0.01)\end{array}$ & 1.02 \\
\hline Non-Maori & $\begin{array}{c}0.03 \\
(0.43)\end{array}$ & 1.03 \\
\hline Competitive electorate & $\begin{array}{r}-0.05 \\
(0.31)\end{array}$ & 0.95 \\
\hline Constant & $\begin{array}{r}-0.74 \\
(0.51)\end{array}$ & \\
\hline$-2 \log$ likelihood & 485.96 & \\
\hline Pseudo $\mathrm{R}^{2}$ & 0.20 & \\
\hline Cases correctly classiffied & 89.43 & \\
\hline $\mathrm{n}$ & 837 & \\
\hline
\end{tabular}

$* * * p<0.01 \quad * * p<0.05 \quad * p<0.10$

Note: Dependent variable is validated vote in the 1996 election held under PR; effect is the unlogged coefficient.

Table 4. Probability of voting under proportional representation (PR) by age and ideological group

\begin{tabular}{lccccccc}
\hline & \multicolumn{3}{c}{ FPP non-voter } & & \multicolumn{3}{c}{ FPP voter } \\
\cline { 2 - 3 } Age & Left & Middle & Non-ideologue* & & Left & Middle & Non-ideologue* \\
\hline $18-35$ & 0.87 & 0.64 & 0.52 & & 0.97 & 0.93 & 0.84 \\
$36-55$ & 0.91 & 0.72 & 0.61 & & 0.98 & 0.93 & 0.88 \\
56 and above & 0.94 & 0.81 & 0.71 & & 0.99 & 0.95 & 0.92 \\
Overall & 0.91 & 0.72 & 0.61 & & 0.98 & 0.93 & 0.88 \\
\hline
\end{tabular}

Note: Estimates derived from Table 3. All other variables held constant at their means and modes.

* Probability for persons on the right is not significantly different from non-ideologues. 


\section{Discussion}

Our analysis suggests that the adoption of PR in New Zealand was responsible for a modest increase in efficacy about voting. Following the first election held under PR in 1996, New Zealanders were more likely to be interested in politics and more likely to believe that their vote counted than in 1990 under FPP. An increase in levels of civic duty, however, occurred during the vote on the electoral reform referendum in 1993. These positive trends in attitudes about voting and civic duty suggest that the adoption of PR may have succeeded in reversing the decline in overall turnout that began in the mid-1980s. The increase in overall turnout is consistent with the cross-national findings of Blais and Dobrzynska (1998), who concluded that PR was responsible for about a 3\% increase in turnout. In particular, our results show that those on the left of the ideological spectrum were more likely to participate than previously. As for Maori, participation increased between 1993 and 1996 to the extent that it made the differences between non-Maori and Maori participation rates insignificant.

However, a few caveats regarding our conclusions are in order. First, our analysis was limited to just one election held under PR, and while some of the effects of institutional change were immediate, others will take more time to measure. Therefore, the full effects of PR on turnout in New Zealand may take another election or two to detect. That we did find significant increases in turnout among particular groups, though, does give us confidence that some change can occur after just one election. Second, New Zealanders are unaccustomed to coalition governments and few anticipated the extended coalition talks that lasted for two months after the 1996 election until a government was formed. The lack of a decisive outcome together with the unexpected coalition of National and New Zealand First, a coalition that neither party's supporters expected or preferred, may have had the effect of making voters feel less efficacious, possibly reversing the positive gains in turnout noted in this analysis.

Overall, the results presented in this paper have implications for electoral reformers as well as students of electoral politics. Although our analysis was restricted to a single country, the results suggest that the adoption of PR can have a positive effect on political efficacy and voter participation, although perhaps not as great as some would have hoped. While institutional change can make people feel more efficacious, more significant gains will depend on the development of the party system. If the transition to PR succeeds in strengthening political parties, then we might expect further increases due to greater mobilisation and stronger party attachments.

\section{References}

Amy, D. 1993. Real Choices/New Voices: The Case for PR Elections in the United States. New York: Columbia University Press.

Anderson, B.A. and B. Silver. 1986. 'Measurement and Mismeasurement of the Validity of the Self-reported Vote.' American Journal of Political Science 30: 771-85.

Australian Electoral Commission. 1999. 'Voter Turnout 1901-1998.' http://www.aec.gov.au/voting/ turnout.htm.

Banducci, S.A., T. Donovan and J.A. Karp. 1999. 'Proportional Representation and Attitudes about Politics: Evidence from New Zealand.' Electoral Studies 18: 533-55.

Banducci, S.A. and J.A. Karp. 1999. 'Perceptions of Fairness and Support for Proportional Representation.' Political Behavior 21: 217-38. 
Blais, A. and R.K. Carty. 1990. 'Does Proportional Representation Foster Voter Turnout?' European Journal of Political Research 18: 167-81.

Blais, A. and A. Dobrzynska. 1998. 'Turnout in Electoral Democracies.' European Journal of Political Research 33: 239-61.

Campbell, A., P.E. Converse, W.E. Miller and D.E. Stokes. 1960. The American Voter. New York: Wiley \& Sons.

Clausen, A.R. 1968. 'Response Validity: Vote Report.' Public Opinion Quarterly 32: 588-606.

Crepaz, M.M.L. 1990. 'The Impact of Party Polarization and Post-materialism on Voter Turnout.' European Journal of Political Research 18: 183-205.

Cronin, T.E. 1989. Direct Democracy: The Politics of Initiative, Referendum, and Recall. Cambridge, MA: Harvard University Press.

Downs, A. 1957. An Economic Theory of Democracy. New York: Harper and Row.

Electoral Commission. 1997. 'The New Zealand Electoral Compendium.'

Franklin, M.N. 1996. 'Electoral Participation.' In Comparing Democracies: Elections and Voting in Global Perspective, eds L. LeDuc, R.G. Niemi and P. Norris. Thousand Oaks, CA: Sage.

Gosnell, H.F. 1930. Why Europe Votes. Chicago: University of Chicago Press.

Granberg, D. and S. Holmberg. 1991. 'Self-reported Turnout and Voter Validation.' American Journal of Political Science 35: 448-59.

Harris, P. 1998. 'Changing New Zealand's Electoral System: Continuity or Crisis?' In Campaign to Coalition: The 1996 MMP Election, eds J. Boston, S. Levine, E. MacLeay and N. Roberts. Palmerston North: Dunmore Press.

Hirczy, W. 1994. 'The Impact of Mandatory Voting Laws on Turnout: A Quasi-experimental Approach.' Electoral Studies 13: 64-76.

Independent Commission on the Voting System. 1998. Report of the Independent Commission on the Voting System. UK: Stationary Office.

Jackman, R.W. 1987. 'Political Institutions and Voter Turnout in the Industrial Democracies.' American Political Science Review 81: 405-23.

Jackman, R.W. and R.A. Miller. 1995. 'Voter Turnout in the Industrial Democracies During the 1980s.' Comparative Political Studies 27: 467-92.

Jesse, E. 1988. 'Split-voting in the Federal Republic of Germany: An Analysis of the Federal Elections from 1953 to 1987.' Electoral Studies 7: 109-24.

Lamare, J.W. and J. Vowles. 1996. 'Party Interest, Public Opinion and Institutional Preferences: Electoral System Change in New Zealand.' Australian Journal of Political Science 31: 321-45.

Lijphart, A. 1999. Patterns of Democracy: Government Forms and Performance in Thirty-six Countries. New Haven: Yale University Press.

Nagel, J.H. 1988. 'Voter Turnout in New Zealand General Elections, 1928-1988.' Political Science 40: $16-38$.

Nagel, J. 1994. 'How Many Parties will New Zealand have under MMP?' Political Science 46: 139-60.

Powell, G.B. Jr. 1980. Voting Turnout in Thirty Democracies: Partisan, Legal, and Socio-Economic Influences. Electoral Participation: A Comparative Analysis, ed R. Rose. Beverly Hills, CA: Sage.

Powell, G.B. Jr. 1986. 'American Voter Turnout in Comparative Perspective.' American Political Science Review 80: 17-43.

Royal Commission on the Electoral System. 1986. Report of the Royal Commission on the Electoral System: Towards a Better Democracy. Wellington: Government Print.

Silver, B.D., B.A. Anderson and P.R. Abramson. 1986. 'Who Overreports Voting? American Political Science Review 80: 613-24.

Sullivan, A. and J. Vowles. 1998. 'Realignment? Maori and the 1996 Election.' In Voters' Victory? New Zealand's First Election Under Proportional Representation, eds J. Vowles, P. Aimer, S. Banducci and J. Karp. Auckland: Auckland University Press.

Swaddle, K. and A. Heath. 1989. 'Official and Reported Turnout in the British General Election of 1987.' British Journal of Political Science 19: 537-70.

Tingsten, H. 1937. Political Behavior: Studies in Election Statistics. London: P.S. King \& Son.

Traugott, M.W. and J.P. Katosh. 1979. 'Response Validity in Surveys of Voting Behavior.' Public Opinion Quarterly 43: 359-77.

Verba, S., N.H. Nie and Jae-On Kim. 1978. Participation and Political Equality: A Seven-nation Comparison. Cambridge: Cambridge University Press.

Vowles, J. 1994. 'Dealignment and Demobilisation? Nonvoting in New Zealand 1938-1990.' Australian Journal of Political Science 29: 96-114. 
Vowles, J. and P. Aimer. 1993. Voters' Vengeance: The 1990 Election in New Zealand and the Fate of the Fourth Labour Government. Auckland: Auckland University Press.

Vowles, J., P. Aimer, S. Banducci and J. Karp (eds). 1998. Voters' Victory? New Zealand's First Election under Proportional Representation. Auckland: Auckland University Press.

Wattenberg, M.P. 1998. 'The Decline of Party Mobilization.' Paper presented at the 1998 annual meeting of the Japanese Political Science Association, Kyoto. 